\title{
PYRITE/PYRRHOTITE MINERAL BASED ELECTROCHEMICAL SENSOR FOR REDOX DETERMINATION IN AQUEOUS MEDIA
}

\author{
Zorka Stanićc $^{*}$, Radmila DŽudović1 ${ }^{1}$, Branislav Vukanović², Ljiljana Jakšíc ${ }^{3}$ \\ ${ }^{1}$ University of Kragujevac, Department of Chemistry, Faculty of Science, R. Domanović 12, \\ P.O. Box 60, 34000 Kragujevac, Serbia \\ ${ }^{2}$ Hygh Polytechnical School, Kosančićeva 35, 37000 Kruševac, Serbia \\ ${ }^{3}$ Faculty of Mining and Geology, University of Belgrade, Djušina 7, 11000 Belgrade, Serbia \\ *Corresponding author; E-mails: zorkas@kg.ac.rs and zorka.stanic@pmf.kg.ac.rs
}

(Received June 22, 2017; Accepted September 8, 2017)

\begin{abstract}
The characterization, construction and performance characteristics of a novel sensor have been carried out. With this purpose, an accurate characterization of the mineral has been performed using scanning electron microscopy (SEM/EDX), X-ray spectrometer and potentiometry. The elemental composition of the sample has been obtained by X-ray microanalysis. The main compounds of the mineral are a pyrite and a pyrrhotite. The potentiometric analysis has allowed investigating some properties of the pyrite/pyrrhotite mineral as a potential sensor material. This technique has also been useful to investigate possibility of using this mineral as indicator electrode for redox determination in aqueous solution. The sensor based on pyrite/pyrrhotite mineral as an electroactive material, displays a stable, reproducible and linear response for iron(III) over concentration range of $10^{-6}-10^{-1} \mathrm{~mol} / \mathrm{L}$ with non-Nernstian slope of $38.7 \pm 0.6 \mathrm{mV}$ per decade. The response time was $10 \mathrm{~s}$. The proposed sensor was applied to determine cobalt(II) and the results were compared with that of a platinum electrode. The determination of $2 \mathrm{mg}$ of cobalt(II) shows an average recovery of $100.9 \%$. The relative standard deviation of this method was $0.5 \%$.
\end{abstract}

Keywords: pyrite/pyrhotite mineral, sensor, potentiometry, redox determination.

\section{INTRODUCTION}

The compounds of iron sulphide, named pyrrhotite $\left(\mathrm{Fe}_{1-\mathrm{x}} \mathrm{S}\right)$, are often associated with pyrite $\left(\mathrm{FeS}_{2}\right)$ in sulphidic ores. The transformation of pyrite in an inert atmosphere proceeds through a multi-step sequential process (pyrite/pyrrhotite/troilite/iron), depending on the temperature in the system (TOULMIN and BARTON, 1964; FERRER and SANCHEZ, 1991; HERAS et al., 1996; LAMBERT et al., 1998; MENG and LiU, 1999; Meng et al., 2002; MENG et al., 2003). The equilibrium composition of the primary pyrrhotite formed by the decomposition of the pyrite is non-stoichiometric and is determined by the temperature. The transformation of the primary pyrrhotite to troilite proceeds gradually. Pyrrhotite with sulfur content between the primary pyrrhotite and troilite can exist as stable phases under certain conditions. The thermal decomposition of pyrite to pyrrhotite seems to follow the unreacted core model and 
may be controlled by zero-order surface reaction, gas film/product layer diffusion, or a combination of these mechanisms, depending on the reaction conditions. In an oxygencontaining atmosphere, pyrite can be oxidized directly or after its decomposition to pyrrhotite (the two-step process) (JORGENSEN and MOYLE, 1982; BRINK et al., 1996; MCLENNAN et al., 2000). This is determined by the relative rates between oxygen diffusion to the pyrite core and the thermal decomposition of the pyrite, and it depends on the actual conditions, such as temperature, oxygen concentration and particle size. In the two-step process, the kinetics of the thermal decomposition of pyrite in an inert atmosphere is expected to be applicable for the first step - the thermal decomposition of the pyrite. The second step - the oxidation of the pyrrhotite, may proceed with pyrrhotite in a solid or a molten state, depending on the particle temperature. Iron oxides (mainly hematite, $\mathrm{Fe}_{2} \mathrm{O}_{3}$, and magnetite, $\mathrm{Fe}_{3} \mathrm{O}_{4}$ ) are the main final products of the oxidation of pyrite. The formation of iron oxides is determined by the temperature and the oxygen concentration at the reaction front. Hematite usually forms at lower temperatures and at higher oxygen concentrations, whereas magnetite at higher temperatures and/or at lowers oxygen concentrations.

Several papers describing electrochemical studies of single samples of iron sulfides have been published, but there have been only a few electrochemical studies concerning mineral mixtures (XU and FINCH 1996; ZHANG et al., 1997). The understanding of the influence of each mineral in a sulfide ore is important to the development of a process suitable to the variety of multi-mineral sulfide ores found in nature. Considerable research has been carried out on the oxidation of pyrite alone using a wide range of methods. Many of these studies concern to metallurgical processing because enhancement of pyrite oxidation may improve the recovery of metals from sulfide ores. In this regard, pyrite was mostly studied by electrochemical techniques (MEYER, 1979; HAMILTON and WOODS, 1981; LOWSON, 1982; AlBERGH et al., 1990; Yin et al., 1999; AlmEIDA and GiAnNETTI, 2002;). Pyrrhotite is a major species among iron sulfides in nature, but there are only a few studies concerning its electrochemical behavior (HAMILTON and WoOdS, 1981; MikHLIN, 2000). Hamilton and Woods (HAMILTON and WoODS, 1981), in a more detailed work, investigated the pyrrhotite dissolution at $\mathrm{pH}$ 4.6, 9.2 and 13.0, employing cyclic voltammetry. There are also a few numbers of surfaces analytical investigations of pyrrhotite reported (BUCKLEY and WOODS, 1985; JONES et al., 1992; PRATT et al., 1994; MikHLin et al., 2000). Many of these investigations were related to the nature of the reactions occurring at the interface between pyrrhotite and air or water during weathering.

Although the oxidative reactions of pyrite and pyrrhotite alone have been studied in some details, the classical approach to study minerals using single specimens can lead to imprecise results. To assess the response of common sulfide minerals to oxidizing conditions, a methodology to immobilize mechanically solid particles on carbon surfaces (voltammetry of microparticles) was employed (ALMEIDA and GIANNETTI, 2003), as well as to define the influence of the pyrrhotite content in pyrite/pyrrhotite mixtures.

The aim of the present work is to show an innovative approach of the electroanalytical investigation of pyrite/pyrrhotite mineral. The novelty of the applied mineral based on pyrite/pyrrhotite is related to its examination from potentiometric point of view as a new sensor material. The analytical applicability of the electrode was examined by measuring the cobalt(II) content in aqueous solution and the results show that this pyrite/pyrrhotite indicator electrode is very promising. Briefly, this study is undertaken in order to add understanding to the mechanism and electrochemical properties of the handmade pyrite/pyrrhotite electrode with a view to its application for redox determination in aqueous media. 


\section{MATERIALS AND METHODS}

\section{Reagents}

All the chemicals used in the present study were of analytical grade from Merck or Fluka. Deionized distilled water was used throughout the experiments. Solution of a cobalt(II) was prepared by weighing out a definite amount of cobalt(II) chloride dihydrate and dissolving it in hydrochloric acid (around $\mathrm{pH}$ 1.4). The concentration of the solution of the cobalt(II) was controlled by titration with standard 0.05 M EDTA using visual end-point detection or potentiometric end-point detection by means of a Pt-SCE couple. Solution of iron(III), $0.05 \mathrm{M}$, was standardized against potasium dichromate. 1,10 phenanthroline (phen) solution, $0.25 \mathrm{M}$, was prepared by dissolving the reagent in hydrochloric acid (around $\mathrm{pH}$ 1.4). The supporting electrolyte was $0.05 \mathrm{M}$ tetrabutylammonium perchlorate, $\mathrm{Bu}_{4} \mathrm{NClO}_{4}$. All measurements were performed at room temperature between 20 and $25{ }^{\circ} \mathrm{C}$. The experiments were carried out with a sample of natural pyrite/pyrrhotite crystal from the Stari Trg mine (Kosovska Mitrovica, Serbia).

\section{Apparatus and electrodes}

Scanning electron microscopy (SEM) images were obtained using an INCA microscope (JEOL JSM-6610LV): X-Max detector, SATW window, WD $17 \mathrm{~mm}$. The surface of polished natural mineral pyrite/pyrrhotite was characterized. The SEM images of the sample was digitalized under the following conditions: voltage, $15 \mathrm{kV}$; spot size, $50 \mathrm{~nm}$; magnification, $20,000 \mathrm{x}$. The photographs correspond to a magnification of $110 \mathrm{x}$. The backscattered electron signal was used for the investigation of specimen surface in the SEM.

The apparatus used to follow the changes in the potential at the pyrite/pyrrhotite electrode over time and for end-point detection with a pyrite/pyrrhotite electrode-SCE couple was described in an earlier paper (STANIĆ et al., 2012). The potential changes during titration were followed with a Digital $870 \mathrm{pH}$ meter (Dresden). The same apparatus with an additional temperature-controlled cell was used to follow the changes in the potential at the employed electrode as a function of the concentration of Fe(III) ions.

The pyrite/pyrrhotite indicator electrode was prepared in the following manner: a piece of the previously analized mineral pyrite/pyrrhotite by SEM $(0.5 \times 0.5 \times 0.3 \mathrm{~cm})$ was used as the sensor material. The electrode had been made by polishing the pyrite/pyrrhotite crystal with diamond paste, and the best polished side was used as the working surface of the electrode. A narrow glass tube was fixed with glue to the other side of the electrode and then filled with mercury. One end of a copper wire was immersed in the mercury, and this device was mounted into a wider glass tube $(\varnothing=1 \mathrm{~cm})$, which was then cemented with a cold sealing mass based on methyl methacrylate. After this mass had solidified, the electrode was rinsed with distilled water and alcohol and dried in air, after which it was ready for use. When the electrode was not used, it was kept in a dry place protected from dust. Before the next use, the electrode was kept in the investigated solvent for half an hour. However, when the electrode was being used frequently (after approximately $10 \mathrm{~h}$ ), it was necessary to rub the pyrite/pyrrhotite crystal with aluminum oxide, wash the electrode, and continue with use. The responses of the pyrite/pyrrhotite indicator electrode were compared with those of a conventional platinum electrode. The reference electrode was a SCE (type 401, Radiometer). 


\section{Procedures}

The newly constructed pyrite/pyrrhotite indicator electrode was calibrated by immersion in conjunction with the reference electrode in a $50 \mathrm{~mL}$ beaker containing water. The ionic strength of the solution was maintained with $0.05 \mathrm{M}$ tetrabutylammonium perchlorate. Then, $1.0 \mathrm{~mL}$ aliquot of $\mathrm{Fe}(\mathrm{III})$ ions solution of different concentration ranging from $10^{-6}$ to $10^{-1} \mathrm{~mol} / \mathrm{L} \mathrm{M}$ was added with continuous stirring. The potential was recorded after stabilization to $\pm 0.2 \mathrm{mV}$ in a temperature-controlled cell $\left(25 \pm 0.1{ }^{\circ} \mathrm{C}\right)$ and the e.m.f. was plotted as function of $\log [\mathrm{Fe}(\mathrm{III})]$. The resulting graph was used for calculation the slope.

The change in the potential of the electrode over time was followed in $0.05 \mathrm{M} \mathrm{Fe}$ (III) ions solution. This indicator electrode was coupled with a SCE as the reference electrode.

The following titration procedure was used: some certain volumes $(25.00 \mathrm{~mL})$ of cobalt(II) solution and phen solution were placed in the volumetric flask $(250 \mathrm{~mL})$. The $\mathrm{pH}$ of solution was adjusted to about 1.4 by adding hydrochloric acid. The solution was than diluted to the mark with distilled water. A $20.00 \mathrm{~mL}$ aliquot of this solution was taken into the titration vessel. The indicator electrode, pyrite/pyrrhotite or a platinum electrode, and a SCE as the reference electrode were immersed in the solution and connected to a $\mathrm{pH}$-meter. Potentiometric titration was then carried out by addition of $0.10 \mathrm{~mL}$ aliquots of a standard $\mathrm{Fe}$ (III) solution. The titration end-point was determined classically from the second derivative of the titration curve. All measurements were carried out under a nitrogen atmosphere at room temperature. The electrochemical cell used for potential measurements was:

reference electrode $\|$ test solution $\|$ indicator electrode.

\section{RESULTS AND DISCUSSION}

\section{Characterization of pyrite/pyrrhotite mineral by scanning electron microscopy and potentiometry}

\section{SEM/EDX analysis}

The elemental analysis of the original natural sample shows the presence of iron and sulphur. In order to characterize the mineral which includes these elements in its composition, a thoroughly exploration of the sample by SEM/EDX was carried out. A phase darker than the mineral easily distinguishable by SEM was observed (Figure 1). X-ray microanalysis of a small area of these particles by SEM/EDX allowed the identification of the following elements: iron and sulphur. The corresponding energy spectrum is shown in Figure 2.

The chemical composition of the particles (see Figures. 1b and 1c), provided by semiquantitative analysis, were found to be significantly similar to those obtained theoretically by the calculation from the elemental formula of the pyrite/pyrrhotite (Table 1). The selected particles indicate that pyrrhotite appeared in conjunction with pyrite on the surface of the natural mineral. 

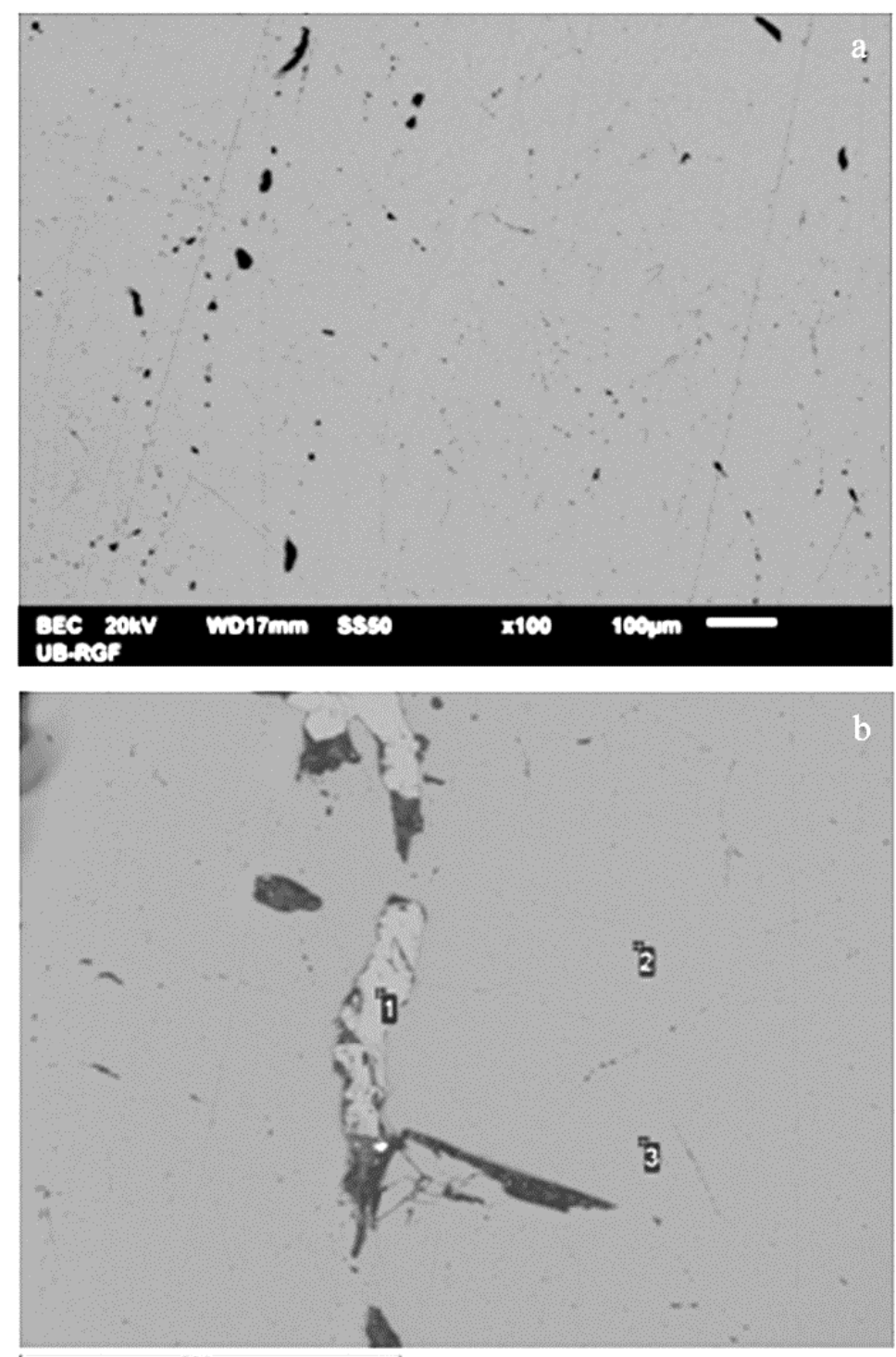

(1)

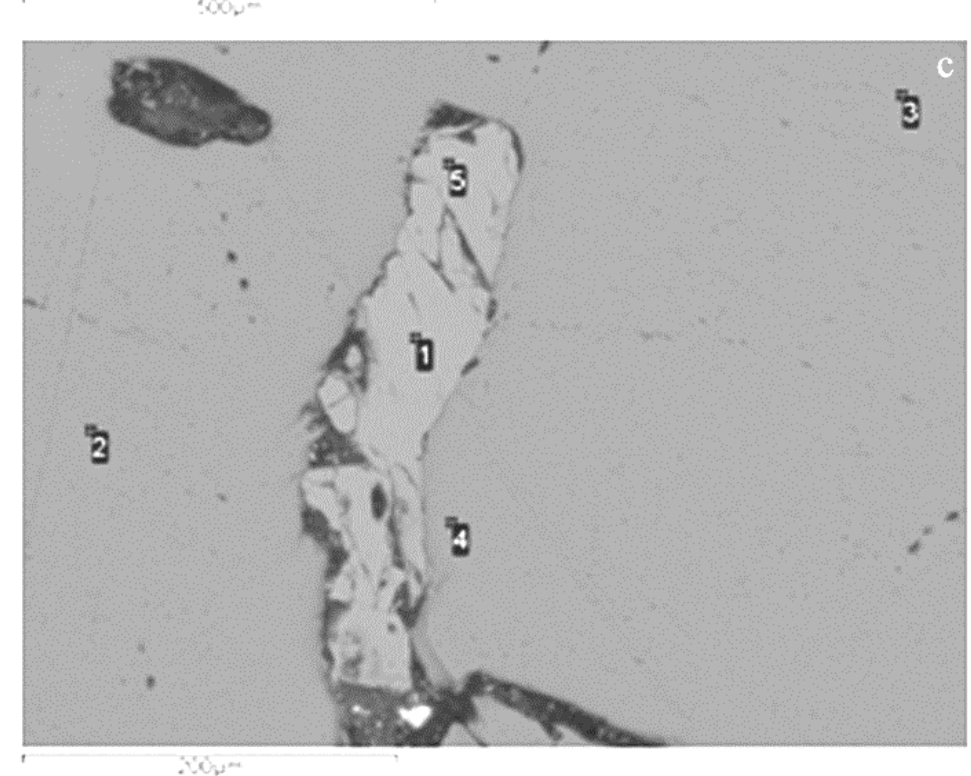

Figure 1. Backscattered electron composition (BEC) images of the pyrite/pyrrhotite surface after smoothing $(\mathbf{a}, \mathbf{b}, \mathbf{c})$. 

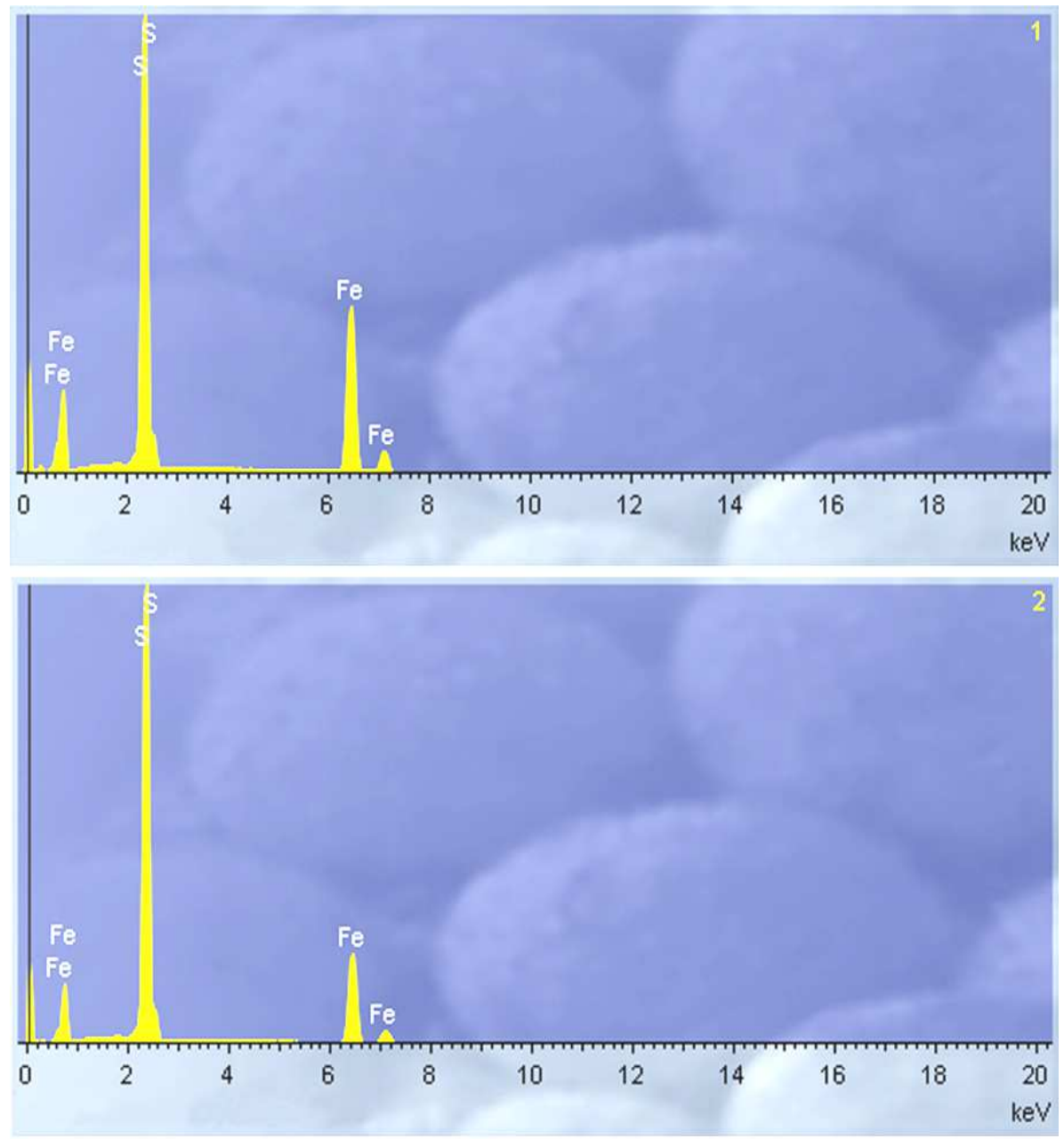

Figure 2. Spectrum of the pyrrhotite (1) and pyrite (2).

Table 1. Semiquantitative elemental composition of the selected particles from I) Figure $1 \mathrm{~b}$ and II) Figure 1c, obtained by X-ray microanalysis.

I)

\begin{tabular}{llll}
\hline Element & $\begin{array}{c}\text { 1-pyrrhotite } \\
\text { (weight \%) }\end{array}$ & \multicolumn{1}{c}{$\begin{array}{c}\text { 2- pyrite } \\
\text { (weight \%) }\end{array}$} & $\begin{array}{c}\text { 3- pyrite } \\
\text { (weight \%) }\end{array}$ \\
\hline S K & 42.59 & 56.24 & 56.51 \\
Fe K & 55.10 & 43.76 & 43.49 \\
Totals & 100.00 & 100.00 & 100.00 \\
\hline
\end{tabular}

II)

\begin{tabular}{llllll}
\hline Element & $\begin{array}{c}\text { 1- pyrrhotite } \\
\text { (weight \%) }\end{array}$ & $\begin{array}{c}\text { 2- pyrite } \\
\text { (weight \%) }\end{array}$ & $\begin{array}{c}\text { 3- pyrite } \\
\text { (weight \%) }\end{array}$ & $\begin{array}{c}\text { 4- pyrite } \\
\text { (weight \%) }\end{array}$ & $\begin{array}{c}\text { 5- pyrrhotite } \\
\text { (weight \%) }\end{array}$ \\
\hline S K & 42.40 & 56.22 & 55.82 & 56.61 & 42.26 \\
Fe K & 57.60 & 43.78 & 44.18 & 43.39 & 57.74 \\
Totals & 100.00 & 100.00 & 100.00 & 100.00 & 100.00 \\
\hline
\end{tabular}




\section{Oxidation of pyrite/pyrrhotite mineral, oxidation products and sensing mechanism of the indicator pyrite/pyrrhotite electrode}

The pyrite dissolution can occur as a direct oxidation. The main oxidant agent is oxygen dissolved in water. Ferric ions can act as catalyzers. The reactions taking place are (MOSES et al., 1987):

$$
\begin{aligned}
& \mathrm{FeS}_{2}+7 / 2 \mathrm{O}_{2}+\mathrm{H}_{2} \mathrm{O} \rightarrow \mathrm{Fe}^{2+}+2 \mathrm{SO}_{4}^{2-}+2 \mathrm{H}^{+} \\
& \mathrm{Fe}^{2+}+1 / 4 \mathrm{O}_{2}+\mathrm{H}^{+} \rightarrow \mathrm{Fe}^{3+}+1 / 2 \mathrm{H}_{2} \mathrm{O}
\end{aligned}
$$

If reaction (2) occurs under acidic conditions, a significant quantity of $\mathrm{Fe}(\mathrm{III})$ will remain in solution:

$$
\mathrm{FeS}_{2}+14 \mathrm{Fe}^{3+}+8 \mathrm{H}_{2} \mathrm{O} \rightarrow 15 \mathrm{Fe}^{2+}+2 \mathrm{SO}_{4}^{2-}+16 \mathrm{H}^{+}
$$

The cathodic reaction involves an aqueous species that accepts electrons from an $\mathrm{Fe}$ (II) site on the mineral surface. This reaction transfer electrons from the surface of the pyrite to the aqueous oxidant species, usually $\mathrm{O}_{2}$ or $\mathrm{Fe}(\mathrm{III})$. At an anodic site, the oxygen atom of a water molecule interacts with a sulfur atom to create a sulfate species. This releases an electron into the solid and hydrogen ions to solution. The final step in the sulfur oxidation process appears to depend upon the $\mathrm{pH}$. Aqueous sulfur products almost $100 \%$ sulfate in low$\mathrm{pH}$ solutions:

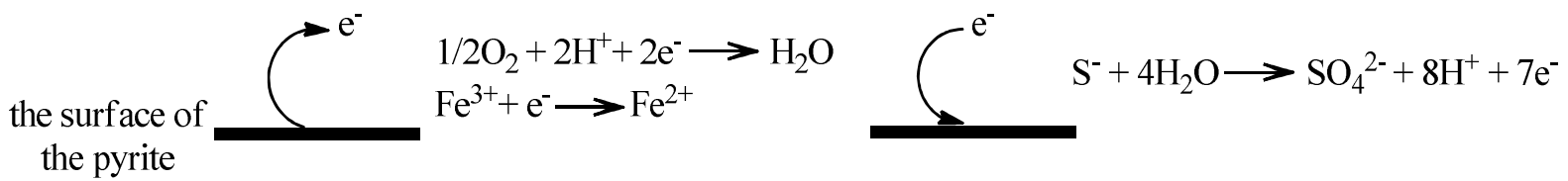

The pyrrhotite reactions and products are difficult to identify. Thomas et al. (THOMAS et al., 2001) add to the oxidative mechanism of pyrrhotite, a non-oxidative dissolving process. The first element to intervene during the oxidative process is the dissolved $\mathrm{O}_{2}$ but, as in the case of pyrite, oxidative force is also provided by $\mathrm{Fe}(\mathrm{III})$ ions, which are then reduced to Fe(II) (THOMAS et al., 1998; THOMAS et al., 2000; THOMAS et al., 2001). In this respect, the presence of $\mathrm{Fe}(\mathrm{III})$ can maintain a cyclic reaction where it acts as an oxidant (BELZILE et al., 2004), according to the reaction represented below:

$$
\mathrm{Fe}_{(1-x)} \mathrm{S}+n \mathrm{Fe}^{3+}+4 \mathrm{H}_{2} \mathrm{O} \rightarrow(1-x+n) \mathrm{Fe}^{2+}+\mathrm{SO}_{4}^{2-}+8 \mathrm{H}^{+}
$$

In the non-oxidative process, there is a consumption of protons with formation of $\mathrm{H}_{2} \mathrm{~S}$. CHIRIŢA et al. (2008) also consider that while $\mathrm{FeS}_{2}$ dissolves only in the presence of an oxidant, FeS does so with or without those in oxidative and non-oxidative processes.

Considering the whole previous discussion, the potential of the pyrite/pyrrhotite electrode can be defined by an equation:

$$
E=E_{\text {const }}+n \log \frac{\left[F e^{3+}\right]}{\left[F e^{2+}\right]}
$$


where $n$ is a slope ( $\mathrm{mV}$ per decade).

\section{Characteristics of the indicator pyrite/pyrrhotite electrode}

In order to employ an ion selective electrode as a sensor in quantitative measurements, a stable potential, a relatively short response time, and a long life-time must be ensured.

Potential of the pyrite/pyrrhotite indicator electrode. The stationary potential of the electrode was measured by direct potentiometry at $25 \pm 0.1{ }^{\circ} \mathrm{C}$ in a freshly prepared $0.05 \mathrm{M}$ solution of $\mathrm{Fe}(\mathrm{III})$. All measurements were performed in the presence of a background electrolyte of constant ionic strength ( $0.05 \mathrm{M}$ tetrabutylammonium perchlorate). A stable potential was acquired for approximately $30 \mathrm{~s}$ (Figure 3 ).

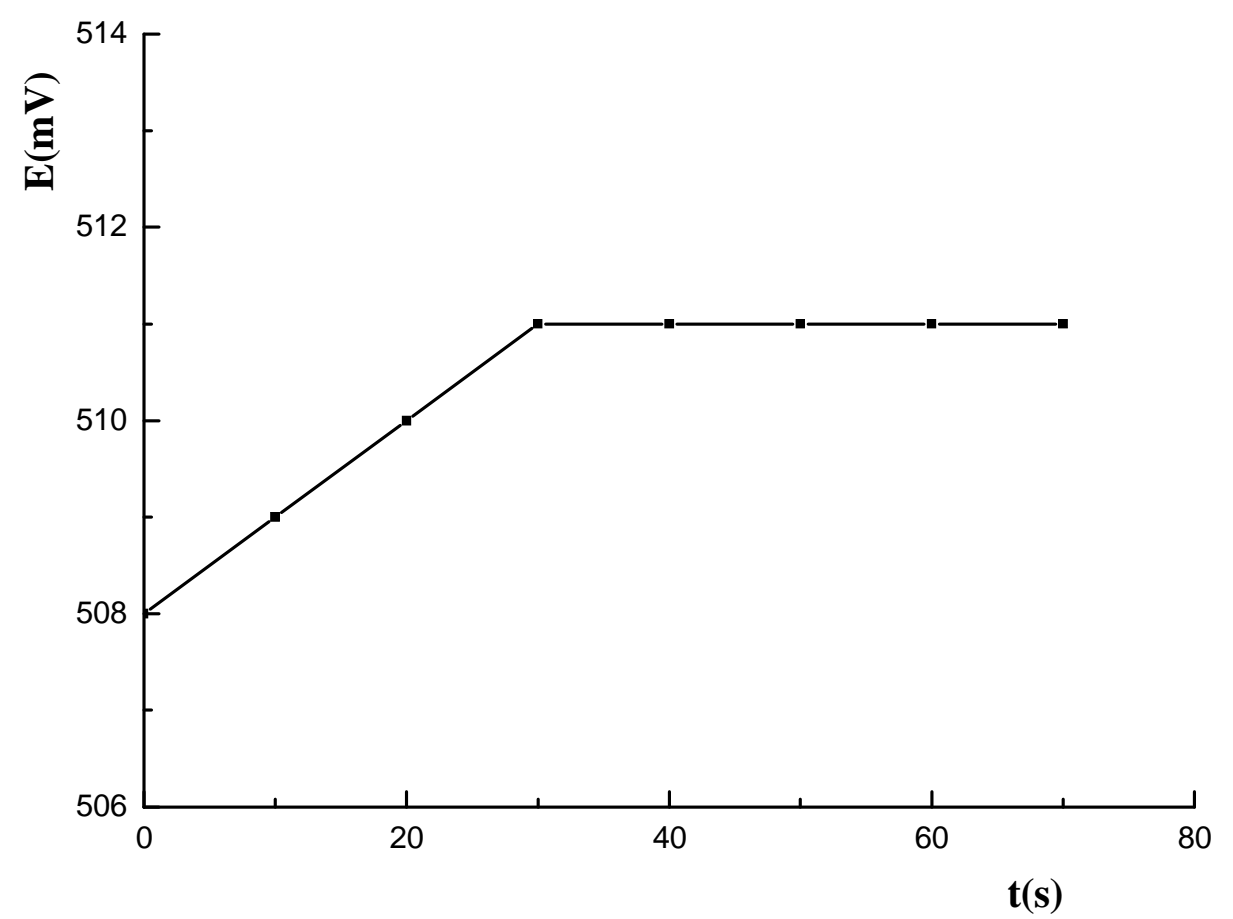

Figure 3. Plot of the pyrite/pyrrhotite electrode potential versus time.

Slope of the potential response of the electrode. The potential of the pyrite/pyrrhotite electrode was determined using a series of Fe(III) in a temperature-controlled cell $(25 \pm 0.1$ ${ }^{\circ} \mathrm{C}$ ). The ionic strength of the solution was maintained with $0.05 \mathrm{M}$ tetrabutylammonium perchlorate. The response characteristic of the electrode is shown in Figure 4. A linear relationship between the signal and concentration was obtained. The potential increased linearly with the concentration of $\mathrm{Fe}(\mathrm{III})$ over the range from $10^{-6}$ to $10^{-1} \mathrm{~mol} / \mathrm{L}$. The slope of calibration line obtained for Fe(III) solutions is $38.7 \pm 0.6 \mathrm{mV}$ per decade. Additionally, the potential of the pyrite/pyrrhotite indicator electrode was very stable with respect to time (Figure 3). Taking these results into account, it can be concluded that this sensor could be successfully applied for redox determination. 


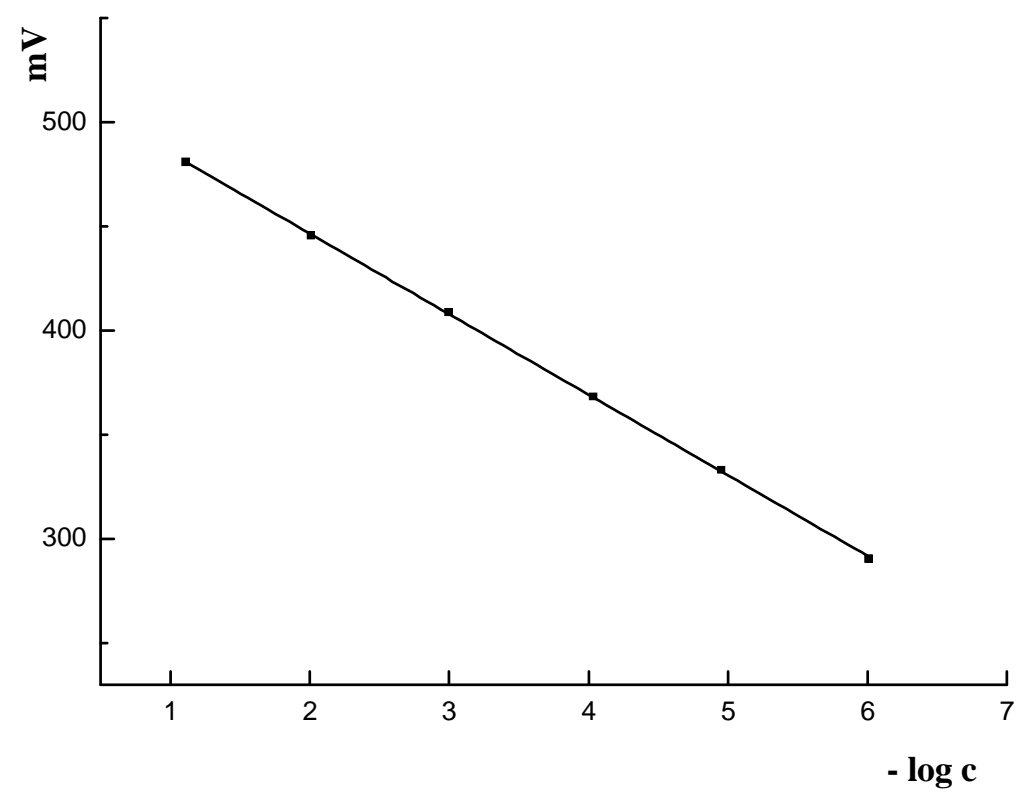

Figure 4. Plot of the pyrite/pyrrhotite electrode potential versus - $\log c$ (concentration) iron(III).

Response time of the electrode. The response time of the pyrite/pyrrhotite electrode was determined by recording the time elapsed before a stable potential value was attained after the pyrite/pyrrhotite electrode and the reference electrode (SCE) were immersed in calibration solutions from low to high concentrations of Fe(III) solutions $\left(10^{-6}-10^{-1} \mathrm{~mol} / \mathrm{L}\right)$. The response time for the electrode was $10 \mathrm{~s}$.

Repeatability. In order to establish the efficiency of the pyrite/pyrrhotite electrode in potentiometric titrations, the titration of $\mathrm{Co}$ (II) with $\mathrm{Fe}$ (III) was taken as a model, and the end point was monitored using this electrode (a Figure is not shown). For six successive determination of $1.86 \mathrm{mg} \mathrm{Co}$ (II) the relative standard deviation (RSD) was $0.52 \%$ (Table 2). Moreover, our investigation showed that the pyrite/pyrrhotite indicator electrode can be used without any time limit and without considerable divergence in the relative standard deviation.

Table 2. Potentiometric titration of cobalt(II) with iron(III) in presence of phen, at the $\mathrm{pH} 1.4$, using pyrite/pyrrhotite and platinum indicator electrodes.

\begin{tabular}{lcccc}
\hline Electrode & $\begin{array}{c}\text { Co } \\
(\mathbf{m g})\end{array}$ & $\begin{array}{c}\text { Phen } \\
(\mathbf{m o l} / \mathbf{L})\end{array}$ & $\begin{array}{c}\text { Found } \\
(\boldsymbol{\%})\end{array}$ & $\begin{array}{c}\text { Standard } \\
\text { deviation } \\
(\boldsymbol{\%})\end{array}$ \\
\hline $\begin{array}{l}\text { pyrite/pyrrhotite } \\
\text { platinum }\end{array}$ & 1.86 & 0.02 & 100.90 & \pm 0.52 \\
& 1.86 & 0.02 & 101.61 & \pm 0.36 \\
\hline
\end{tabular}

*Number of determinations: 6

Long-term stability. The lifetime of the electrode was determined by raising the potential values of the calibration solution, Fe(III), and plotting the calibration curves for a period of two years. The slope of the electrode remained constant. Nevertheless, if the electrode had been used frequently and for a long time, it was necessary to rub the crystal pyrite/pyrrhotite with aluminum oxide, wash the electrode and continue with use. 
Based on the obtained results it can be assumed that the pyrite/pyrrhotite electrode would probably be a good sensor for the detection of the titration end-point (TEP) in redox reactions.

\section{Application to an end-point indication of the pyrite/pyrrhotite electrode}

The practical utility of the proposed sensor was tested by its use as indicator electrode for the potentiometric titration of cobalt(II) with iron(III). However, direct oxidation of Co(II) by $\mathrm{Fe}$ (III) is quite decidedly unfavorable and does not occur. It is well known that complexing agents modify the redox potential of a redox system involving metal ions. In general, this phenomenon has a potential capacity for the development of various redox reactions in the presence of a suitable complexing agent. Because of complexation with 1,10 phenanthroline, the formal reduction potential of the cobalt species in greatly diminished, while that of the iron species is appreciably increased; consequently, the oxidation of $\mathrm{Co}$ (II) by $\mathrm{Fe}$ (III) becomes highly favorable (VYDRA and PřIBIL, 1959; VYDRA and PřIBIL, 1960). The enhanced oxidation strength of iron(III) salts in the presence of 1,10 phenanthroline was utilized for determination of cobalt(II).

When phen forms complex with cobalt(II) and $\mathrm{Co}(\mathrm{III})$, the conditional redox potential of the $\mathrm{Co}(\mathrm{III}) / \mathrm{Co}(\mathrm{II})$ system can be written as:

$$
E^{\prime}=E^{0}+0.059 \log \frac{\alpha_{C o(I I)(p h e n)}}{\alpha_{C o(I I I)(p h e n)}}+0.059 \log \frac{C_{C o(I I I)}}{C_{C o(I I)}}
$$

where $\alpha$ refers to the side-reaction coefficient taking into account the complex formation of $\mathrm{Co}(\mathrm{III})$ and $\mathrm{Co}(\mathrm{II})$ with phen. $C_{C o(I I I)}$ and $C_{C o(I I)}$ are the total concentrations of $\mathrm{Co}(\mathrm{III})$ and $\mathrm{Co}(\mathrm{II})$, respectively. In the presence of phen, the conditional redox potential of the $\mathrm{Co}(\mathrm{III}) / \mathrm{Co}$ (II) system is sufficiently lower than those of the $\mathrm{Fe}(\mathrm{III}) / \mathrm{Fe}(\mathrm{II})$ system. Accordingly, the oxidation reaction of $\mathrm{Co}$ (II) to $\mathrm{Co}$ (III) by $\mathrm{Fe}(\mathrm{III})$ is favored in the presence of phen.

In this work, the determination of $\mathrm{Co}$ (II) was performed in presence of optimal

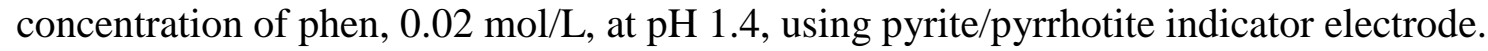

The change of the electrode potential for the pyrite/pyrrhotite electrode is ranged from 400 to $900 \mathrm{mV}$ (Figure 5). The titration curve is symmetrical with a very well defined potential jump indicating the high sensitivity of the electrode. The potential during the titration and at the equivalence point were rapidly established (within a few minutes). The potential jumps at TEP obtained by using pyrite/pyrrhotite electrode are similar to those obtained with platinum electrode and sufficiently large to allow the precise determination of this compound under the conditions employed using a pyrite/pyrrhotite electrode. In the titration of $0.001 \mathrm{M}$ cobalt(II) with iron(III) in presence of phen, the jumps at TEP were 160 $\mathrm{mV} / 0.1 \mathrm{~mL}$ and $150 \mathrm{mV} / 0.1 \mathrm{~mL}$ for the pyrite/pyrrhotite and platinum electrodes, respectively. 


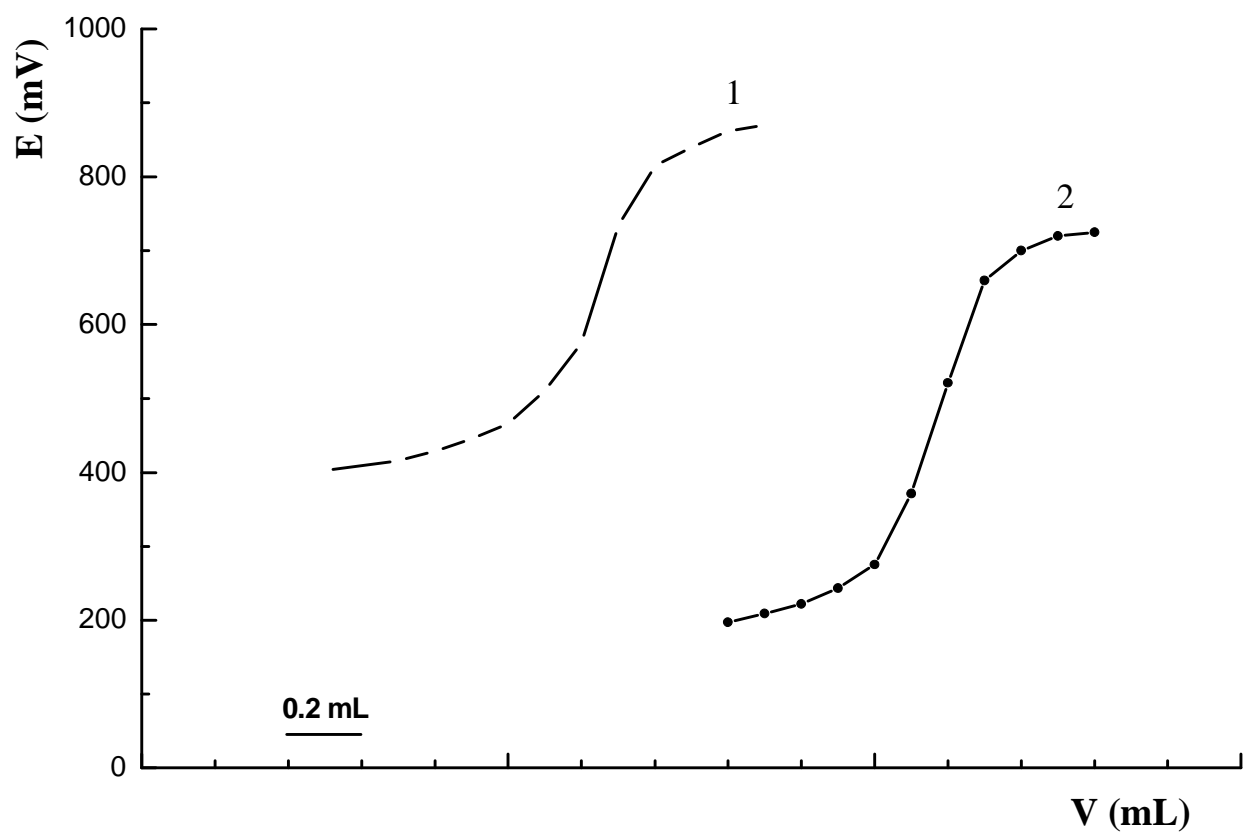

Figure 5. The effect of (1) pyrite/pyrrhotite and (2) platinum indicator electrode on the shape of the end-point inflexion in the potentiometric titration of cobalt(II) with iron(III) in presence of phen.

The potentiometric titration of cobalt(II) with iron(III) was carried out at $\mathrm{pH} 1.4$, in the presence of 1,10-phenanthroline, using pyrite/pyrrhotite indicator electrode. It was found that the average recovery was unsatisfactory in the presence of different concentrations of phen. The effect of the concentration of phen was examined at concentrations from 0.006 to $0.020 \mathrm{~mol} / \mathrm{L}$. The results are shown in Figure 6 . Satisfactory results were obtained in the presence of phen at concentrations higher than $0.01 \mathrm{~mol} / \mathrm{L}$.

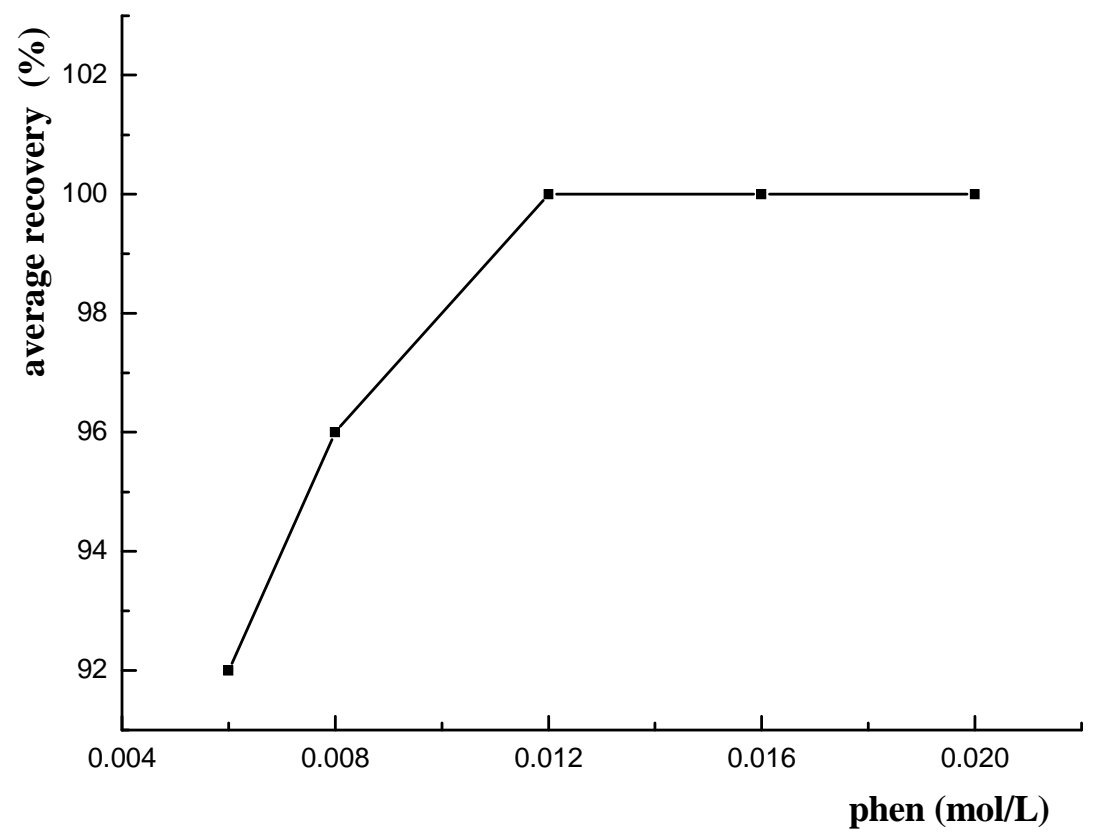

Figure 6. The effect of phen concentration on average recovery using pyrite/pyrrhotite indicator electrode.

The results obtained in the determination of cobalt(II) using a pyrite/pyrrhotite indicator electrode (Table 2) deviated on average about $\pm 0.5 \%$ from those obtained with a 
platinum electrode. This standard deviation is in the acceptable range, indicating that the electrode can be efficiently used in redox determinations.

The effect of diverse ions on the titration of $0.001 \mathrm{~mol} / \mathrm{L} \mathrm{Co}$ (II) with $\mathrm{Fe}(\mathrm{III})$ in the presence of $0.02 \mathrm{~mol} / \mathrm{L}$ phen, using a pyrite/pyrrhotite indicator electrode, was also examined. The following ions have no influence: $\mathrm{Na}(\mathrm{I}), \mathrm{K}(\mathrm{I}), \mathrm{Mg}(\mathrm{II}), \mathrm{Ca}(\mathrm{II}), \mathrm{Cl}^{-}, \mathrm{NO}_{3}{ }^{-}(0.1 \mathrm{~mol} / \mathrm{L})$; $\mathrm{Al}(\mathrm{III}), \mathrm{Mn}(\mathrm{II}), \mathrm{Ni}(\mathrm{II}), \mathrm{Zn}(\mathrm{II}), \mathrm{Pb}(\mathrm{II})(0.001 \mathrm{~mol} / \mathrm{L}) . \mathrm{Ce}(\mathrm{IV})$ caused a positive interference in the titration of $\mathrm{Co}(\mathrm{II})$, because $\mathrm{Ce}(\mathrm{IV})$ oxidized $\mathrm{Fe}(\mathrm{II})$ to $\mathrm{Fe}(\mathrm{III})$. On the contrary, V(V) and $\mathrm{Fe}(\mathrm{III})$ caused negative interferences in this titration, because cobalt(II) was oxidized by these ions.

\section{CONCLUSION}

The study by scanning electron microscopy and X-ray microanalysis allows deducing that the investigated mineral was essentially made of pyrite and pyrrhotite. The performance and detection mechanism of this mineral, used as an electroactive material for a new sensor, have been studied and discussed. The sensor is easily and quickly prepared using inexpensive and nontoxic material.

As verified in this paper, a pyrite/pyrrhotite mineral could be used as a sensor material of the indicator electrode for redox determination of cobalt(II) by iron(III) in aqueous media. Furthermore, the sensor could be applied for determination other ions, which opens lots of possibilities for the development of practical redox sensor. Thanks to the robustness and chemical inertness of the mineral it is possible to be also applied in non-aqueous environment.

\section{Acknowledgments}

This work is supported by the Ministry of Education, Science and Technological Development of the Republic of Serbia (Project No. 172036). The authors wish to thank Dr. Suzana Erić, Assistant Professor for SEM results.

\section{References:}

[1] Albergh, E., Forssberg, K.S.E., WANG, X. (1990): The surface oxidation of pyrite in alkaline solution. J Appl Electrochem 20 (6): 1033-1039. doi: 10.1007/BF01019585

[2] Almeida, C.M.V.B., Giannetti, B.F. (2002): Comparative study of electrochemical and thermal oxidation of pyrite. J Solid State Electrochem 6 (2): 111-118.

doi: $10.1007 / \mathrm{s} 100080100200$

[3] Almeida, C.M.V.B., GiannetTi, B.F. (2003): The electrochemical behavior of pyritepyrrhotite mixtures. J Electroanal Chem 553: 27-34.

doi: 10.1016/S0022-0728(03)00254-7

[4] Belzile, N., Chen, Y.W., CAI, M.F., LI, Y. (2004): A review on pyrrhotite oxidation. J. Geochem Explor 84 (2): 65-76. doi: 10.1016/j.gexplo.2004.03.003

[5] Brink, H.M., Eenkhoorn, S., Hamburg, G. (1996): A fundamental investigation of the flame kinetics of coal pyrite. Fuel 75 (8): 945-951. doi: 10.1016/00162361(96)00049-X 
[6] Buckley, A.N., Woods, R. (1985): X-ray photoelectron spectroscopy of oxidized pyrrhotite surfaces. I. Exposure to air. Appl Surf Sci 22/23 (1): 280-287.

doi: 10.1016/0378-5963(85)90061-3

[7] ChirițĂ, P., Descostes, M., Schlegel, M.L. (2008): Oxidation of FeS by oxygenbearing acidic solutions. J Colloid Interf Sci 321 (1): 84-95.

doi: 10.1016/j.jcis.2008.01.024

[8] Ferrer, I.J., SAnchez, C. (1991): Characterization of $\mathrm{FeS}_{2}$ thin films prepared by thermal sulfidation of flash evaporated iron. J Appl Phys 70 (5): 2641-2647. doi: $0.1063 / 1.349377$

[9] Hamilton, I.C., Woods, R. (1981): An investigation of surface oxidation of pyrite and pyrrhotite by linear potential sweep voltammetry. J Electroanal Chem 118: 327-343. doi: 10.1016/S0022-0728(81)80551-7

[10] Heras, C., Martin de Vidales, J.L., Ferrer, I.J., SAnchez, C. (1996): Structural and Microstructural Features of Pyrite $\mathrm{FeS}_{2-\mathrm{x}}$ Thin Films Obtained by Thermal Sulfuration of Iron. J Mater Res 11 (1): 211-220. doi: 10.1557/JMR.1996.0026

[11] Jones, C.F., Lecount, S., Smart, R.S.C., White, T.J. (1992): Compositional and structural alteration of pyrrhotite surfaces in solution: XPS and XRD studies. Appl Surf Sci 55 (1): 65-85. doi: 10.1016/0169-4332(92)90382-8

[12] Jorgensen, F.R.A., Moyle, F.J. (1982): Phases formed during the thermal analysis of pyrite in air. $J$ Therm Anal 25 (2): 473-485. doi: 10.1007/BF01912973

[13] Lambert, J.M., Simkovich, G., Walke, P.L. (1998): The Kinetics and Mechanism of the Pyrite-to-Pyrrhotite Transformation. Metall Mater Trans B 29B (2): 385-396. doi: $10.1007 / \mathrm{s} 11663-998-0115-\mathrm{x}$

[14] Lowson, R.T. (1982): Aqueous oxidation of pyrite by molecular oxygen. Chem Rev 82 (5): 461-497. doi: 10.1021/cr00051a001

[15] Mclennan, A.R., Bryant, G.W., Stanmore, B.R., Wall, T.F. (2000): Ash formation mechanisms during pf combustion in reducing conditions. Energy Fuels 14 (1): 150159. doi: 10.1021/ef990095u

[16] Meng, L., LiU, M.S. (1999): Thin pyrite $\left(\mathrm{FeS}_{2}\right)$ films prepared by thermal-sulfurating iron films at various temperatures. Mater Sci Eng B 60 (3): 168-172. doi: 10.1016/S0921-5107(99)00083-5

[17] Meng, L., LiU, Y.H., Huang, W. (2002): Synthesis of pyrite thin films obtained by thermal-sulfurating iron films at different sulfur atmosphere pressure. Mater Sci Eng B 90 (1): 84-89. doi: 0.1016/S0921-5107(01)00930-8

[18] Meng, L., LiU, Y.H., Tian, L. (2003): Evolutions of structure, composition and optical absorption behavior of pyrite films formed by sulfurating iron. Mater Res Bull $\mathbf{3 8}$ (6): 941-948. doi: 10.1016/S0025-5408(03)00085-0

[19] MeYER, R.E. (1979): Electrochemistry of $\mathrm{FeS}_{2}$. J Electroanal Chem 101 (1): 59-71. doi: 10.1016/S0022-0728(79)80079-0

[20] Mikhlin, Y., Varnek, V., Asanov, I., Tomashevich, Y., Okotrub, A., Livshits, A., Selyutin, G., PAShKov, G. (2000): Reactivity of pyrrhotite $\left(\mathrm{Fe}_{9} \mathrm{~S}_{10}\right)$ surfaces: Spectroscopic studies. Phys Chem Chem Phys 2 (19): 4393-4398. doi: 10.1039/B005372O 
[21] Mikhlin, Y. (2000): Reactivity of pyrrhotite surfaces: An electrochemical study. Phys Chem Chem Phys 2 (24): 5672-5677. doi: 10.1039/B005373M

[22] Moses, C.O., Nordstrom, D.K., Herman, J.S., Mills, A.L. (1987): Aqueous pyrite oxidation by dissolved oxygen and by ferric iron. Geochim Cosmochim Acta 51 (6): 1561-1571. doi: 10.1016/0016-7037(87)90337-1

[23] Pratt, A.R., Muir, I.J., NesBitT, H.W. (1994): X-ray photoelectron and Auger electron spectroscopic studies of pyrrhotite and mechanism of aie oxidation. Geochim Cosmochim Acta 58 (2): 827-841. doi: 10.1016/0016-7037(94)90508-8

[24]STANić, Z.; Dimić, T.; SiMIĆ, Z. (2012): Noble metal oxides electrodes and analytical application thereof for acid-base titrations in non-aqueous solvents. J Electrochem Soc 159 (5): J168-J175. doi: 10.1149/2.057205jes

[25] Thomas, J.E., Jones, C.F., Skinner, W.M., Smart, R.S. (1998): The role of surface sulfur species in the inhibition of pyrrhotite dissolution in acid conditions. Geochim Cosmochim Acta 62 (9): 1555-1565.

[26] Thomas, J.E., Skinner, W.M., Smart, R.S. (2001): A mechanism to explain sudden changes in rates and products for pyrrhotite dissolution in acid solution. Geochim Cosmochim Acta 65 (1): 1-12. doi: 10.1016/S0016-7037(00)00503-2

[27] Thomas, J.E., Smart, R.S., Skinner, W.M. (2000): Kinetic factors for oxidative and nonoxidative dissolution of iron sulfides. Miner Eng 13 (10-11): 1149-1159. doi: 10.1016/S0892-6875(00)00098-4

[28] Toulmin, P., BARTON, P.B. (1964): A thermodynamic study of pyrite and pyrrhotite. Geochim Cosmochim Acta 28 (5): 641-671. doi: 10.1016/0016-7037(64)90083-3

[29] VYDRA, F., PŘIBIL, R. (1959): New redox systems-I. Oxidation of bivalent cobalt with iron $^{\text {III }}$ chloride in 1:10-phenanthroline solutions. Talanta 3 (1): 103-104. doi: 10.1016/0039-9140(59)80178-8

[30] VYDRA, F., PŘIBIL, R. (1960): New redox systems-II: Oxidation of cobalt ${ }^{\mathrm{II}}$ with iron ${ }^{\mathrm{III}}$ chloride in 1:10-phenanthroline solutions. Talanta 5 (1): 44-52. doi: 10.1016/00399140(60)80204-4

[31] XU, Z., FINCH, J.A. (1996): A direct method for studying collector adsorption on minerals in a mixed mineral system. Trans IMM 105: C197-C199.

[32] Yin, Q., Kelsall, G.H., Vaughan, D.J., Welham, N.J. (1999): Rotating Ring (Pt)Disc $\left(\mathrm{FeS}_{2}\right)$ Electrode Behavior in Hydrochloric Solutions. J Colloid Interf Sci 210 (2): 375-383. doi: 10.1006/jcis.1998.5921

[33] Zhang, Q., XU, Z., Bozkurt, V., Finch, J.A. (1997): Pyrite flotation in the presence of metal ions and sphalerite. Int J Miner Process 52 (2-3): 187-201. doi: 10.1016/S03017516(97)00064-1 